\title{
Modification of four-stroke engine for operation in two-stroke cycle for automotive application
}

The main disadvantages of two-stroke engines such a big fuel consumption and big emission of hydrocarbons or carbon monoxide can be reduced by new proposal of design of two stroke engine based on four stroke engines. The paper describes the operation of high supercharged spark ignition overhead poppet valve two-stroke engine, which enables to achieve higher total efficiency and exhaust gas emission comparable to four-stroke engines. The work of such engines is possible by proper choice of valve timings, geometrical parameters of inlet and outlet ducts and charge pressure. The engine has to be equipped with direct fuel injection system enabling lower emission of pollutants. The work is based on theoretical considerations and engine parameters are determined on the simulation process by use GT-Power program and CFD program for different engine configurations. The initial results included in the paper show influence of valve timing on engine work parameters and predicted exhaust gas emission. The simulation results show that the nitrogen oxides are considerably reduced in comparison to four-stroke engines because of higher internal exhaust gas recirculation. The innovation of this proposal is applying of variable valve timing with turbocharging system in the two-stroke engine and obtaining a significant downsizing effect. The conclusions shows the possibilities of applying two-stroke poppet valve engine as a power unit for transportation means with higher total efficiency than traditional engines with possible change of engine operation in two modes: two- and four stroke cycles.

Key words: transport, engine development, two-stroke engine, boosting

\section{Modyfikacja silnika czterosuwowego do obiegu dwusuwowego do zastosowań motoryzacyjnych}

\begin{abstract}
Główne wady silników dwusuwowych, takie jak duże zużycie paliwa i duża emisja węglowodorów oraz tlenku węgla moga być wyeliminowane przez propozycję nowej konstrukcji silnika 2-suwowego opartego na silniku 4-suwowym. W artykule przedstawiono prace wysoko doładowanego górnozaworowego silnika 2-suwowego, który umożliwia uzyskanie większej sprawności niż silnika 4-suwowego przy utrzymaniu emisji szkodliwych składników spalin na poziomie silników 4-suwowych. Silnik jest wyposażony w bezpośredni wtrysk paliwa umożliwiający mniejsza emisję szkodliwych sktadników spalin. Przedstawiono osiagi silnika, które określono na podstawie symulacji w programie GT-Power oraz przy użciu programu CFD. Silnik zostat zmodyfikowany przez zmiane systemu zaworowego i faz rozrzadu dla pracy $w$ cyklu 2-suwowym. Zaprezentowano zmiany zachodzace $w$ parametrach termodynamicznych cylindra $w$ czasie wymiany tadunku dla wersji 2- $i$ 4-suwowej. Proces spalania byt modelowany za pomoca prostych reakcji kinetycznych dla węglowodorów i tlenków azotu oraz reakcji dysocjacji. Wyniki symulacji wskazują, że emisja tlenków azotu jest znacznie mniejsza w porównaniu z silnikiem 4-suwowym z powodu dużej wewnętrznej recyrkulacji spalin. Innowacja w proponowanym silniku dwusuwowym jest zmienność faz rozrzadu z doładowaniem turbosprężarkowym i uzyskanie znacznego zmniejszenia gabarytów silnika (downsizing). Podano także możliwość zastosowania górnozaworowego silnika 2-suwowego jako jednostki napędowej dla środków transportu o większej sprawności niż tradycjne silniki, z możliwościa pracy zarówno w cyklu 2-suwowym, jak i 4-suwowym.
\end{abstract}

Słowa kluczowe: transport, silniki spalinowe, doładowanie, spalanie, sprawność silnika

\section{Innovation technology in two-stroke engines}

The two-stroke engines are still competitive in operation parameters and production costs in comparison to four-stroke engines, particularly in transport means. Nevertheless, they seem to be completely forgotten as a power unit for passenger cars. Despite of their numerous advantages as low production cost, low weight and simple structure, they have disadvantages that caused the above mentioned situation. The most important factor is short interval between maintenance and high emission of hydrocarbons. Because four-stroke engines haven't got such problems, they are almost totally squeezed out their competitors.

In spite of this situation, main disadvantages of two-stoke engines can be reduced by new proposal of design of two stroke engine based on four stroke engines structure, provid-

\section{Innowacyjna technologia silników dwusuwowych}

Silniki dwusuwowe w odniesieniu do parametrów roboczych i kosztów wytwarzania są ciągle konkurencyjne w stosunku do silników czterosuwowych, szczególnie w małych środkach transportowych. Jednak wydaje się, że są całkowicie pominięte jako jednostki zasilania dla samochodów osobowych. Mimo ich licznych zalet, jak niskie koszty produkcji, mała masa i prosta konstrukcja, mają wady, które spowodowały powyższą sytuację. Najważniejszymi wadami są: krótki okres międzynaprawczy, duża emisja węglowodorów oraz duże zużycie paliwa. Ponieważ silniki czterosuwowe nie mają takich problemów, są one niemal całkowicie bezkonkurencyjne. Jednak główne wady silników dwusuwowych mogą być zredukowane dzięki nowym propo- 
ing additional benefits of this kind of engine development as increased engine efficiency. Four-stroke internal combustion engines have been highly modernized and improved during last years. Despite of their numerous disadvantages, it owes the market success to perfect combination of manufacturing cost, performance and ecological properties. Recently many researchers and scientists proposed two-stroke engine with valve timing for automotive application as for example $\mathrm{Na}$ kano [9] and Ricardo [10] and also numerical calculations were carried out for example by Das and Dent [3].

Last years the authors of this paper published their investigations with poppet valve two-stroke engine applied for automotive sector [6-8]. Especially, recent increase of mechanical efficiency by downsizing kept the four-stroke engine development at a high level. Nevertheless, it seems that we are achieving the limit of four-stroke engine performance nowadays. High thermal and mechanical load or risk of engine knock presents the threshold in contemporary high efficient four-stroke engines. Further reduction of brake specific fuel consumption (BSFC) of this type of engine is hardly possible without any innovative design changes.

One of innovation approach to achieve this goal is a reducing two idle strokes: intake and exhaust in order to obtain significant reduction in mechanical losses. It simply means the return of two-stroke engine as a common power source with direct fuel injection. The new two-stroke engine will not produce high amount of hydrocarbons and obtain long time between overhauls thus disposes of the most important disadvantages of the predecessor. This can be achieved by application of common four-stroke engine structure with its intake and exhaust poppet valves and crankcase intended for lubricating purposes to the engine working in a two-stroke mode. Nowadays variable valve timing systems are commonly applied in modern four-stroke engines. However, the most promised is electro-hydraulic system enabling flexible control of valve timing and is suitable for poppet valve two-stroke engine. This enables the engine work both in two- and four-stroke operation dependently on engine loads and speeds. Such system was developed by Ricardo

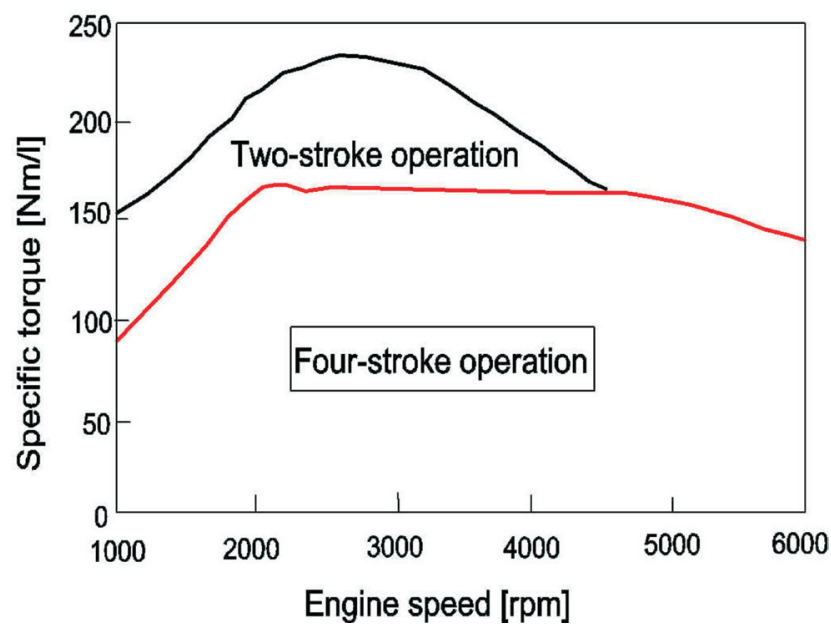

Fig. 1. 2/4-stroke engine operating strategy [10] Rys. 1. Strategia pracy silnika w trybie 2/4-suwowym [10] zycjom rozwiązań konstrukcyjnych silników dwusuwowych, opierających się na strukturze silników czterosuwowych, zapewniając dodatkowe korzyści z tego rodzaju silników, jak zwiększona sprawność pracy silnika. Czterosuwowe silniki spalinowe bardzo zmodernizowano i ulepszono w ciągu ostatnich lat. Mimo swoich licznych wad, silniki te zawdzięczają „sukces rynkowy” doskonałemu połączeniu niskich kosztów produkcji, wysokich osiągów i dobrych właściwości ekologicznych. W ostatnich latach wielu badaczy i naukowców zaproponowało dwusuwowy silnik z rozrządem zaworowym na potrzeby motoryzacji, np. Nakano [9] i firma Ricardo [10]. Także przeprowadzono wiele numerycznych obliczeń, na przykład przez Dasa i Denta [3].

W poprzednich latach autorzy niniejszej pracy opublikowali wyniki swoich badań silnika dwusuwowego z zaworem grzybkowym do zastosowania w sektorze motoryzacyjnym $[6,7,8]$. Szczególnie preferowany jest ostatnio wzrost sprawności mechanicznej przez zmniejszenie wymiarów czterosuwowego silnika o dużych parametrach roboczych. Jednak wydaje się, że obecnie jest kres uzyskiwania dużych osiągów czterosuwowego silnika. Wysokie obciążenia termiczne i mechaniczne lub ryzyko spalania stukowego w silniku powodują powstanie granicy możliwości efektywnej pracy współczesnych silników czterosuwowych. Dalsze zmniejszenie jednostkowego zużycia paliwa $\left(\mathrm{g}_{\mathrm{e}}\right)$ tego typu silnika jest prawie niemożliwe bez innowacyjnych zmian konstrukcyjnych. Jedną z innowacji do osiągnięcia tego celu jest zmniejszenie dwóch jałowych suwów: ssania i wylotu, aby uzyskać znaczące zmniejszenie strat mechanicznych. Oznacza to powrót do idei silnika dwusuwowego, jako wspólnego źródła mocy z bezpośrednim wtryskiem paliwa. Nowy silnik dwusuwowy nie wydziela dużych ilości węglowodorów, uzyskuje długi czas międzynaprawczy i w ten sposób pozbywa się najważniejszych wad swego poprzednika. Można to osiągnąć dzięki zastosowaniu wspólnego systemu z czterosuwowego silnika z jego zaworowym rozrządem wlotu i wylotu oraz skrzynią korbową przeznaczoną tylko do celów smarowania w silniku pracującym w trybie dwusuwowym. Obecnie systemy zmiennych faz rozrządu są powszechnie stosowane w nowoczesnych silnikach czterosuwowych. Jednak najbardziej korzystny jest układ elektrohydrauliczny umożliwiający elastyczne sterowanie fazami rozrządu. Jest on odpowiedni do zaworowego silnika dwusuwowego, pozwala na pracę silnika zarówno w trybie dwu-, jak i czterosuwowym, zależnie od obciążenia silnika i prędkości obrotowej. System ten został opracowany przez Ricardo [10], a charakterystykę takiego silnika dla dwóch trybów pracy przedstawiono na rys. 1 .

Cykl dwusuwowy pozwala zmniejszyć wymiary ze względu na to, że suw pracy występuje dwukrotnie częściej niż w silniku czterosuwowym. Oznacza to, że ta sama wielkość silnika dwusuwowego z takim samym średnim ciśnieniem efektywnym $\mathrm{p}_{\mathrm{e}}$ (BMEP) wytwarza około dwa razy większą moc niż silnik czterosuwowy, co może być wyrażone zależnością (1),

gdzie: $\mathrm{N}_{\mathrm{e}}$ - moc efektywna, BMEP - średnie ciśnienie efektywne, $\mathrm{V}_{\mathrm{ss}}$ - objętość skokowa silnika, $\mathrm{n}$ - prędkość obrotowa 
[10] and engine performance for two mode operations is presented in Fig. 1.

Two-stroke cycle enables to obtain a significant downsizing effect because of fact, that power strokes occur twice as frequent as in the four-stroke engine. This means that the same size of the two-stroke engine working with comparable BMEP produce ca. twice as much power as the four-stroke engine, what can be expressed by relation:

$$
\mathrm{N}_{\mathrm{e}}=\frac{\mathrm{BMEP} \cdot \mathrm{V}_{\mathrm{ss}} \cdot \mathrm{n}}{\mathrm{k}}
$$

where: $\mathrm{N}_{\mathrm{e}}$ - brake power, BMEP - brake mean effective pressure, $\mathrm{V}_{\mathrm{ss}}$ - engine displacement, $\mathrm{n}$ - engine speed, $\mathrm{k}$ engine cycle factor $(k=2$ for four-stroke engine and $k=1$ for two-stroke one).

\section{Designing of automotive two-stroke engine}

From an engineering point of view it is known that remaining of the same power is possible by decreasing of the engine displacement in two-stroke engine application. This modification reduces engine friction losses in two ways. Firstly, it decreases mean piston speed by decreasing piston stroke. It seams that it would be feasible by applying fourstroke engine structure to build a two-stroke engine. The most important modification is to change camshaft drive, which has to rotate at the same speed as crankshaft. Remaining the crankcase space for lubricating purposes guarantees long time between overhauls but forces to apply either long piston skirt with scraper ring and porting control of gas exchange into cylinder or poppet valves in the cylinder head.

The first solution reduces the durability of engine in comparison with the second one, especially because of damage effect of the piston fire ring collaborating with engine liner port, so it has to be rejected. In this connection, poppet valves seems to be the proper choice, but they cause problems with gas flow because of less flow area-time characteristic compared with ports placed in cylinder liner. As turbocharger becomes a standard equipment of internal combustion engines, what should occur in near future, it would be possible to scavenge the cylinder using both intake and exhaust poppet valves.

Of course the additional charger have to be implemented in order to exchange the cylinder gases properly in a transient states, but twin charger four-stroke engines have been already produced so it shouldn't increase the overall cost of two-stroke engine in comparison with the four-stroke. Above mentioned conception forces to use well controlled air-charge system to ensure proper scavenge in all engine steady and transient operating states. Probably the most feasible layout of this system is shown in Fig. 2.

The increased blow-down angle (IVO-EVO) in comparison with piston ported two-stoke engine (TOEO) enables a decrease of cylinder silnika, $\mathrm{k}$ - współczynnik trybu pracy $(\mathrm{k}=2$ dla silnika czterosuwowego i $\mathrm{k}=1$ dla silnika dwusuwowego).

\section{Konstrukcja samochodowego silnika dwusuwowego}

Z inżynierskiego punktu widzenia wiadomo, że uzyskanie tej samej mocy jest możliwe przez zmniejszenie objętości skokowej w silniku dwusuwowym. Taka modyfikacja zmniejsza straty tarcia w silniku przez zmniejszenie średniej prędkości tłoka oraz przez zmniejszenie skoku tłoka. Wydaje się możliwe wykorzystanie konstrukcji silnika czterosuwowego do budowy silnika dwusuwowego. Najważniejszą modyfikacją jest zmiana napędu wałka rozrządu, który musi obracać się z taką samą prędkością obrotową jak wał korbowy. Pozostawienie przestrzeni skrzyni korbowej tylko do celów smarowania zapewnia długi okres użytkowania, lecz wymusza zastosowanie długiego płaszcza tłoka z pierścieniem zgarniającym oleju oraz sterowanie wymiany gazu w cylindrze za pomocą zaworów grzybkowych w głowicy silnika.

Pierwsze rozwiązanie zmniejsza żywotność silnika w porównaniu z drugim rozwiązaniem, ponieważ uszkodzenie pierścienia tłokowego współpracującego z okienkami cylindra jest wyeliminowane. W takim zestawieniu zawory grzybkowe wydają się właściwym wyborem, lecz wywołują problem przepływu gazu z powodu mniejszego czasoprzekroju przepływu gazu w porównaniu z okienkami umieszczonymi w tulei cylindrowej. Zespół turbosprężarki staje się standardowym wyposażeniem w silnikach spalinowych i możliwe jest przepłukanie przy zastosowaniu zarówno grzybkowego zaworu dolotowego, jak i wylotowego. Oczywiście dodatkowy układ doładowujący powinien być zastosowany w celu właściwej wymiany ładunku w stanach nieustalonych, lecz podwójny układ doładowania jest już produkowany tak, że nie powinno to wpływać na ogólny koszt silnika dwusuwowego w porównaniu z silnikiem czterosuwowym. Podana koncepcja wymusza zastosowanie dobrego systemu sterowania doładowaniem powietrza w celu zapewnienia właściwego przepłukania podczas wszystkich ustalonych i nieustalonych stanów pracy. Prawdopodobnie najbardziej realny układ takiego systemu przedstawiono na rys. 2 .

Powiększony kąt wypływu gazów (IVO-EVO), $\mathrm{w}$ porównaniu $\mathrm{z}$ dwusuwowym silnikiem $\mathrm{z}$ rozrządem tłokowo-szczelinowym (TO-EO), zmniejsza ciśnienie $\mathrm{w}$ cylindrze $\mathrm{w}$ chwili otwarcia zaworu dolotowego i w ten 
pressure at opening of intake valve and thus

a) prevents fresh air of excessive backflow. The late valve closing gives opportunity to retain a sufficient scavenge angle and additionally change ratio between compression and expansion angle, what leads to better conversion of internal energy of burned gasses to piston work.

By using variable valve timing system two-stroke engine can work with non-symmetrical scavenge process, which enables better cylinder filling by fresh air (Fig. 2). Typical valve timing in piston engines is realized by applying of camshaft where the cams have constant position relative to the shaft. The best realization of valve opening and closing for the proposed engine is shown in Fig. 3.

\section{Work parameters of two- and four- stroke engines}

In order to investigate the feasibility of proper scavenging and obtain main engine characteristics, several analyses have been performed. All of them have been carried out in GT-Power software [4] as one-dimensional simulations for engine Lombardini LGA 340. The results of this type of simulations are preliminary and have to be supplemented with proper $3 \mathrm{D}$ analysis in order to obtain reliable model response.

Decreasing of engine fuel consumption reduces vehicle carbon dioxides emission, thus low BSFC should be a target in a modern two-stroke engine design. In order to obtain proper comparison data, two engines were simulated in GTPower software: four- and two-stroke. Both of them were developed of the same base four-stroke engine. The only difference occurred in valve timing, where left diagram of Fig. 3 was applied in the two-stroke version.

The pressure variation of four-stroke engine and twostroke engine is shown in Fig. 4. For the same maximum pressure the two-stroke engine indicates two-times higher power than four-stroke engine with the same bore and stroke. However in real conditions, because of worse scavenge process, the two-stroke engine IMEP will be lower than in four stroke engine. Because of fact, that turbo charging wasn't a target of performed analysis, only a pressure difference between intake and exhaust ducts was considered for modelling of the scavenging process.

It was assumed, that intake overpressure was produced completely by turbocharger, and thus no additional mechanical energy losses were to be included. The adjusting of engine load can be performed by intake pressure (VTG, waste gate etc.) without throttle application in entire range of engine operating conditions. In this type of adjustment, the additional compressor has to be applied in order to provide a sufficient amount of fresh air during engine acceleration (transient states) and start.

The benefits of two-stroke engine application instead of four-stroke one may be even better because comparison b)

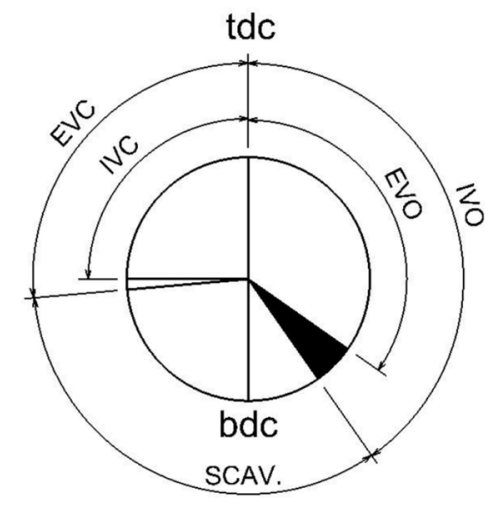

iston ported two stoke engine
valve two-stroke engine (b)

typowego silnika dwusuwowego sterowanego tlokiem (a) i fazy rozrzadu zaworowego silnika dwusuwowego (b)

sposób zapobiega znacznemu cofaniu świeżego powietrza. Późniejsze zamknięcie zaworu daje możliwość zachowania wystarczającego kąta przepłukania i dodatkowo zmienia stosunek kątów sprężania i rozprężania, co prowadzi do lepszej konwersji energii wewnętrznej gazów spalinowych na pracę tłoka.

Przy zastosowaniu systemu rozrządu o zmiennych fazach silnik dwusuwowy może pracować z niesymetrycznym systemem przepłukania, który daje lepsze napełnienie cylindra świeżym powietrzem (rys. 2). Typowy system rozrządu w silnikach tłokowych jest realizowany przez wałek krzywkowy, w którym krzywki utrzymują stałe położenie względem wałka. Najlepsza realizacja otwarcia i zamknięcia zaworów dla proponowanego silnika jest przedstawiona na rys. 3 .

\section{Parametry pracy silników dwu- i czterosuwowych}

Do zbadania wykonalności odpowiedniego systemu przepłukania i uzyskania głównych parametrów silnika przeprowadzono wiele analiz. Wszystkie analizy były przeprowadzone za pomoca oprogramowania GT-Power i otrzymano rozwiązania z 1-wymiarowego modelu obliczeniowego dla silnika Lombardini LGA 340. Wyniki obliczeń symulacji są wstępne i muszą być uzupełnione wynikami analiz 3D.

Zmniejszenie zużycia paliwa w silniku zmniejsza również emisję dwutlenku węgla; w ten sposób mniejsze $\mathrm{g}_{\mathrm{e}}$ powinno być celem konstrukcji nowoczesnego dwusuwowego silnika. Do uzyskania właściwych danych porównawczych obydwa typy silników: dwu- i czterosuwowy były poddane symulacji w programie GT-Power. Obydwie symulacje przeprowadzono na tym samym bazowym silniku czterosuwowym. Jedyna różnica polegała na przyjęciu innych faz rozrządu, gdzie lewy szkic na rys. 3 reprezentuje rozrząd klasycznego silnika dwusuwowego.

Przebieg ciśnienia w cylindrze silnika czterosuwowego i dwusuwowego jest pokazany na rys. 4. Przy tym samym maksymalnym ciśnieniu silnik dwusuwowy wykazuje dwukrotnie większą moc niż silnik czterosuwowy o tej samej 


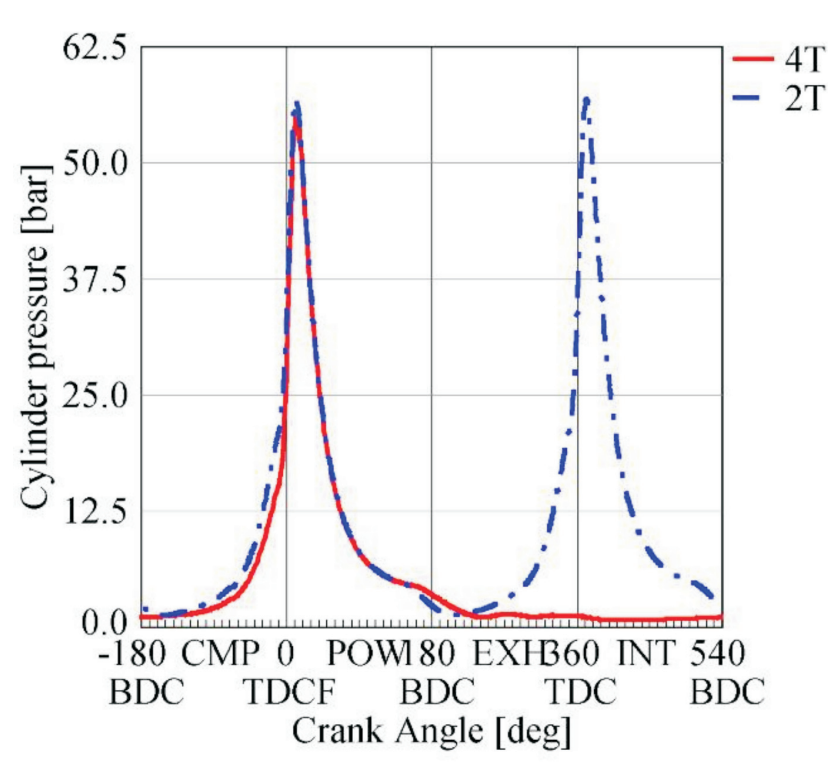

Fig. 4. Two- (2T) and four-stroke engine (4T) cylinder pressure during operation with equal maximum pressure

Rys. 4. Przebieg ciśnienia w cylindrze dla silnika dwu- (2T) i czterosuwowego (4T) przy zachowaniu jednakowego maksymalnego ciśnienia

was carried out on same size engine, where two-stroke variant produced more than twice as much power as the competitor.

In order to expose advantages of modification of typical four-stroke engine to operate in two-stroke mode, BSFC maps of both four- and two-stroke engines have been prepared (see Fig. 5). The empty zones of two-stroke engine map are caused by specific simulation approach - engine load was set by determination of pressure difference between air filter inlet end exhaust pipe outlet. The lowest value of this difference was specified as 0.4 bar and this was the reason of empty bottom left zone occurrence (Fig. 5a). The top right empty zone was generated in connection with top limit of above-mentioned pressure difference ( 2 bar) and średnicy cylindra i skoku tłoka. Jednakże w rzeczywistych warunkach, z powodu gorszego procesu przepłukania, średnie ciśnienie indykowane $\mathrm{p}_{\mathrm{i}}$ będzie mniejsze niż $\mathrm{w}$ silniku czterosuwowym. $Z$ powodu tego, że turbodoładowanie nie było celem przeprowadzonej analizy, tylko różnica ciśnień między kanałem dolotowym i wylotowym była uwzględniona do zamodelowania procesu przepłukania.

Założono, że nadciśnienie w przewodzie dolotowym jest wytworzone przez turbosprężarkę, co spowodowało, że nie występują dodatkowe straty mechaniczne. Regulacja obciążenia silnika może być dokonana przez zmianę ciśnienia na dolocie (VGT, zawór upustowy itp.) bez udziału przepustnicy powietrza w całym zakresie pracy silnika. Przy tym rodzaju regulacji dodatkowa sprężarka powinna być zastosowana, aby zapewnić wystarczającą ilość powietrza podczas przyspieszania (stany przejściowe) i rozruchu.

Korzyści z zastosowania silnika dwusuwowego zamiast silnika czterosuwowego mogą być jeszcze większe, ponieważ porównanie było przeprowadzone przy tych samych wymiarach silnika, gdzie wersja dwusuwowa wytwarzała ponad dwukrotnie większą moc niż silnik czterosuwowy.

Aby uwypuklić korzyści wynikające z modyfikacji typowego czterosuwowego silnika do pracy w trybie dwusuwowym sporządzono mapę jednostkowego zużycia paliwa $\left(\mathrm{g}_{\mathrm{e}}\right)$ zarówno dla cztero-, jak i dwusuwowego silnika (rys. 5). Puste strefy na mapie silnika dwusuwowego są spowodowane specyfiką procesu symulacji - obciążenie silnika było określane przez różnicę ciśnień między filtrem powietrza a układem wylotowym gazów spalinowych. Najniższa różnica ciśnień była przyjęta jako 0,4 bar i to było przyczyną wystąpienia pustych obszarów w dolnym lewym rogu mapy (rys. 5a). Górny prawy pusty obszar był generowany w wyniku przyjęcia górnej granicy różnicy ciśnień ( 2 bary) i ostatni pusty obszar $-\mathrm{z}$ powodu prawdopodobnego wystąpienia spalania stukowego. Należy zauważyć, że przy tym samym $\mathrm{p}_{\mathrm{e}}$ (9 bar jako maksimum dla czterosuwowego silnika) silnik dwusuwowy uzyskuje około $27 \mathrm{~g} / \mathrm{kW} \cdot \mathrm{h}$ mniejsze $\mathrm{g}_{\mathrm{e}}$. a)

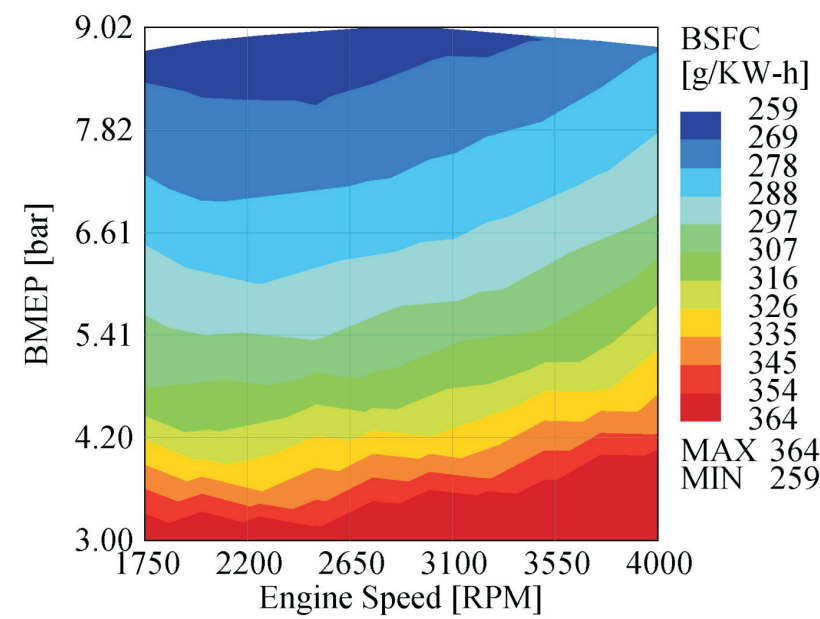

b)

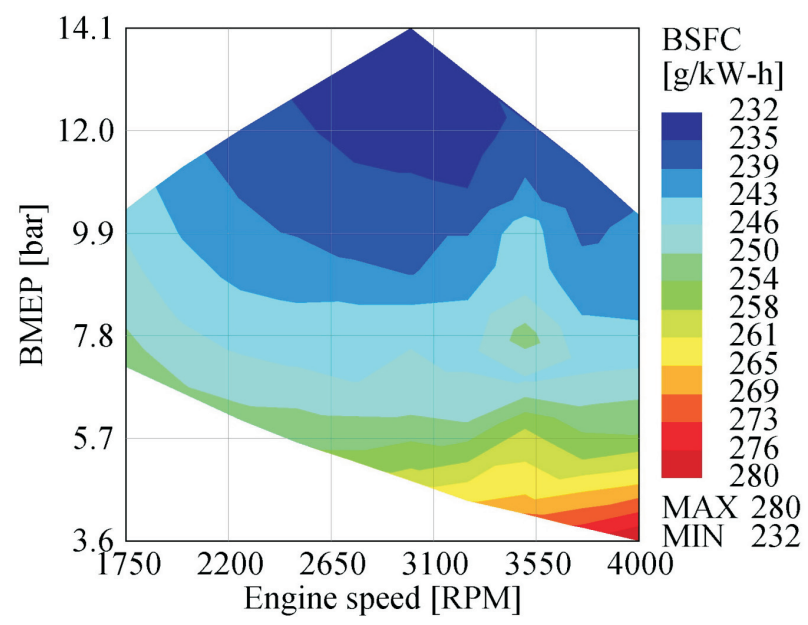

Fig. 5. BSFC map of 4-stroke engine (a) and 2-stroke engine with poppet valves (b) Rys. 5. Mapa jednostkowego zużycia paliwa dla 4-suwowego silnika (a) i 2-suwowego (b) 
the last empty zone by probability of engine knock. It can be noticed that at the same BMEP ( 9 bar as a maximum of four-stroke engine) the two-stroke engine obtain ca. 27 $\mathrm{g} / \mathrm{kW} \cdot \mathrm{h}$ lower BSFC.

This is caused especially by better transformation of incylinder energy to mechanical work (valve timing of right scatter plot in Fig. 3 have been applied) and obvious reduction of necessary strokes. After taking into consideration entire twostroke engine operating area, the drop of BSFC in comparison with four-stroke engine rises up to $27 \mathrm{~g} / \mathrm{kW} \cdot \mathrm{h}$. It presents ca. $3.8 \%$ rise of brake efficiency. The empty area in both of presented maps limits the engine operating states because of high peak firing pressure occurrence (above 75 bar).

\section{Exchange of the charge in poppet two-stroke engine}

The one of the most important factors influencing on high volumetric efficiency is scavenge process during opening poppet valves. It can be noticed that time of exhaust gas outflow and air inflow is very short for two-stroke mode operation particularly for higher rotational speeds. Full cycle of two-stroke engine work was simulated in CFD by using of KIVA3V program. For simulation of engine physical processes the engine Yaris 2SZ-FE with capacity $1.3 \mathrm{dm}^{3}$ was used. The mesh of one cylinder was prepared in KIVA pre-processor for comparison for two versions: the first with standard inlet pipes and the second with vertical inlet pipes (Fig. 6).

The simulation was carried out at assumption of charging ratio 1.8 and direct fuel injection with fuel dose $0.022 \mathrm{~g} / \mathrm{cycle}$ and was carried out at $3000 \mathrm{rpm}$. Opening and closing of inlet valves were set as $150 \mathrm{deg}$ ATDC and $110 \mathrm{deg}$ BTDC, however opening of exhaust valves were set $110 \mathrm{deg}$ ATDC and closing of them 140 BTDC. Setting of inlet pipes and charging pressure influence on air inflow to the cylinder.

a)

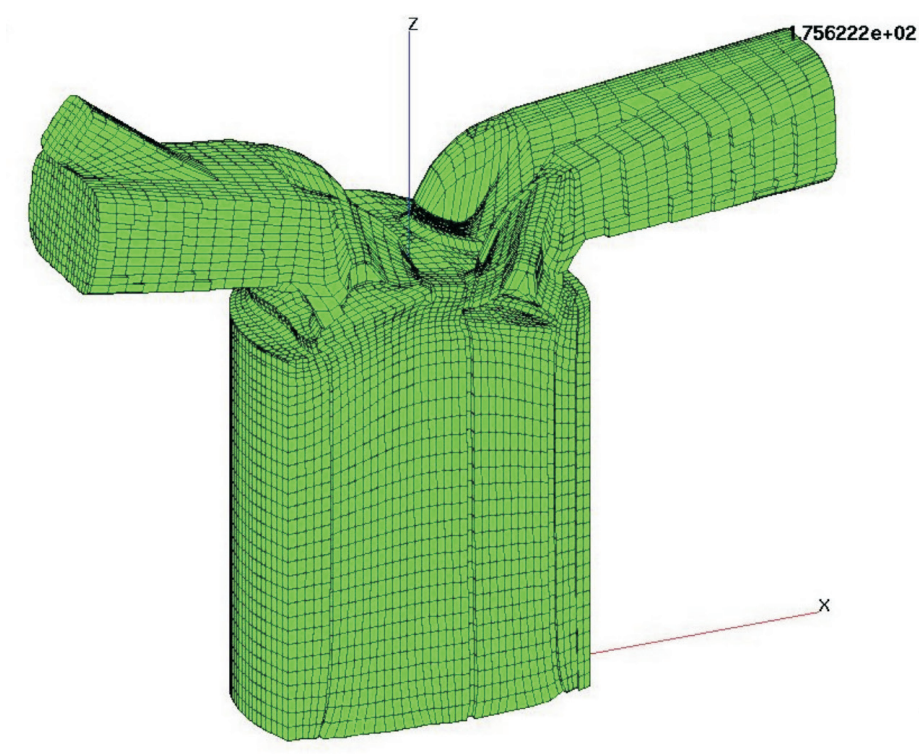

b)
Jest to spowodowane szczególnie lepszą konwersją energii w cylindrze na pracę mechaniczną (zostały przyjęte fazy rozrządu wg rys. 3 po prawej stronie) i zmniejszeniem ilości suwów. Po przyjęciu do rozważań wstępnych parametrów operacyjnych silnika dwusuwowego spadek $\mathrm{g}_{\mathrm{e}} \mathrm{w}$ porównaniu do silnika czterosuwowego zwiększył się do $27 \mathrm{~g} / \mathrm{kW} \cdot \mathrm{h}$. To powoduje około 3,8-procentowy wzrost sprawności ogólnej silnika. Puste obszary na obydwu przedstawionych mapach pokazują granice stanów pracy silników z powodu wystąpienia dużego maksymalnego ciśnienia spalania (powyżej 75 bar).

\section{Wymiana ladunku w zaworowym silniku dwusuwowym}

Jednym z najważniejszych czynników wpływających na duży stopień napełnienia jest proces przepłukania podczas otwarcia zaworów grzybkowych. Należy zauważyć, że czas wypływu gazów spalinowych i wlotu powietrza jest bardzo krótki przy pracy w wersji dwusuwowej, szczególnie przy dużych prędkościach obrotowych. Pełny cykl roboczy silnika dwusuwowego był symulowany za pomocą techniki CFD przy użyciu programu KIVA3V. Do symulacji procesów fizycznych wykorzystano model geometryczny silnika YARIS 2SZ-FE o objętości skokowej 1,3 $\mathrm{dm}^{3}$. Siatka obliczeniowa silnika została przygotowana przez preprocesor KIVA w celu porównania dla dwóch wersji: w pierwszej ze standardowym wlotem powietrza i dla drugiej wersji z pionowym kanałem wlotowym (rys. 6).

Symulacja była przeprowadzona przy założeniu stopnia doładowania 1,8 i zastosowaniu bezpośredniego wtrysku paliwa $\mathrm{z}$ dawką paliwa $0,022 \mathrm{~g} / \mathrm{cykl}$ oraz przy prędkości obrotowej $3000 \mathrm{obr} / \mathrm{min}$. Otwarcie i zamknięcie zaworu dolotowego było odpowiednio ustawione jako $150{ }^{\circ} \mathrm{OWK}$ po GMP i $110^{\circ} \mathrm{OWK}$ przed GMP, przy czym otwarcie i zamknięcie zaworów wylotowych przyjęto odpowiednio jako

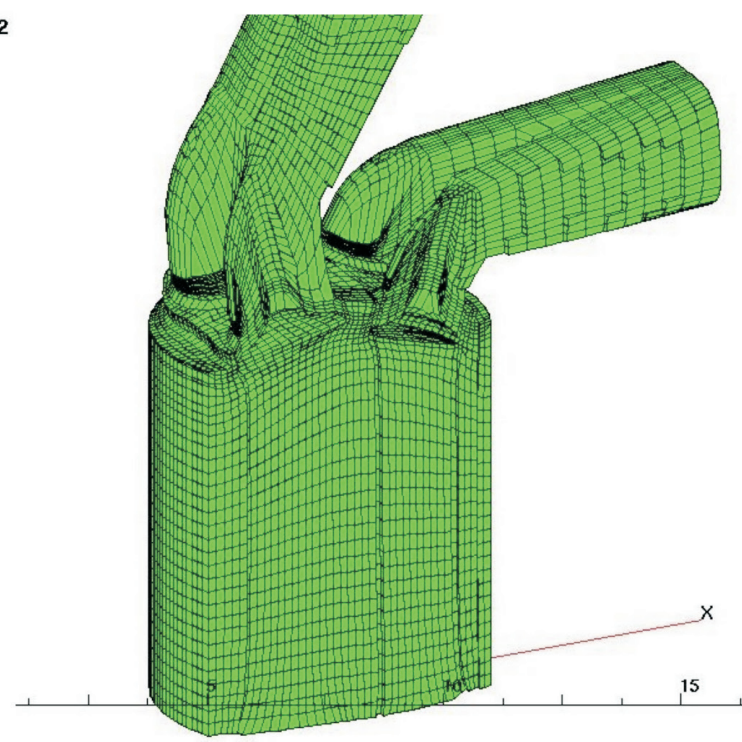

Fig. 6. Cylinder mesh with a) standard inlet pipes, b) vertical inlet pipes

Rys. 6. Siatka cylindra ze standardowym (a) i pionowym (b) kanałem wlotowym 
a)

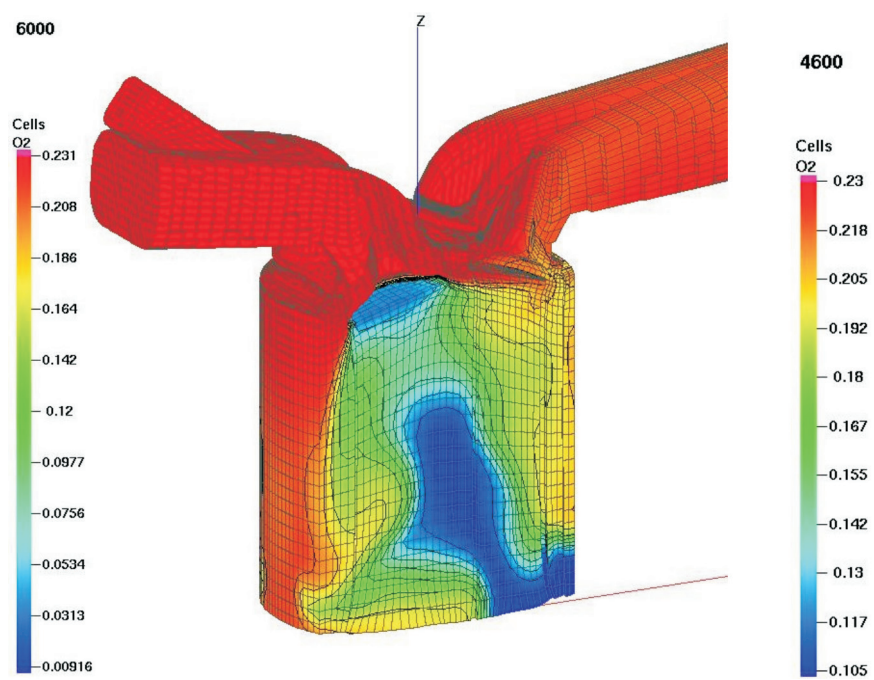

b)

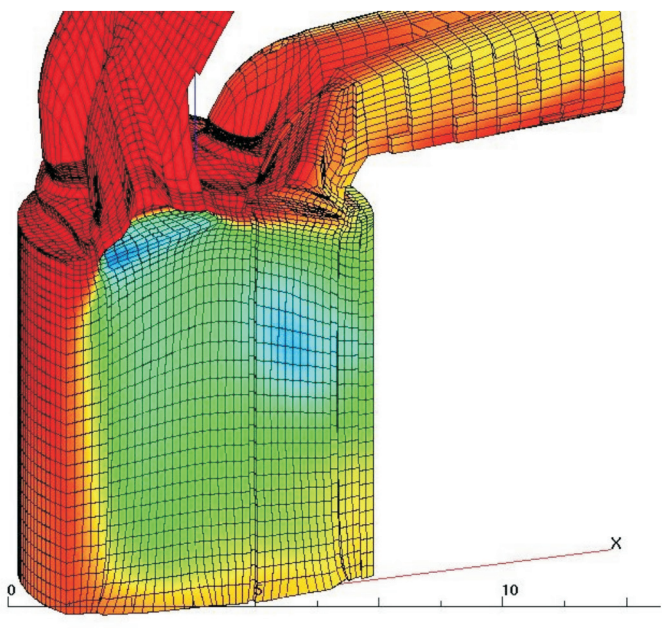

Fig. 7. Oxygen mass ratio during charge exchange in cylinder with standard inlet pipes (a) and vertical inlet pipes (b) Rys. 7. Udział masowy tlenu podczas wymiany ładunku w cylindrze ze standardowym (a) i pionowym (b) kanatem dolotowym

Engine with standard inlet pipes showed higher air flow to the exhaust ducts and lower cleaning of the cylinder from residual gas (lower volumetric efficiency). The centre of cylinder is filled by exhaust gases. The second case show more even distribution of air inside the cylinder. This case enables more intensive movement of the charge (higher "tumble") than the standard version. Distribution of mass ratio of oxygen (proportional also the air) for both cases at $140 \mathrm{deg}$ BTDC is shown in Fig. 7.

Higher "tumble" in the cylinder with vertical inlet pipes is confirmed by calculation of angular momentums related to xyz axis. The evident differences are seen for angular momentum related to y-axis My (Fig. 8), where a rapid increase of that value occurs for vertical inlet pipe at 230 $\operatorname{deg}$ (130 deg BTDC). This case is more useful for poppet valve two-stroke engine.

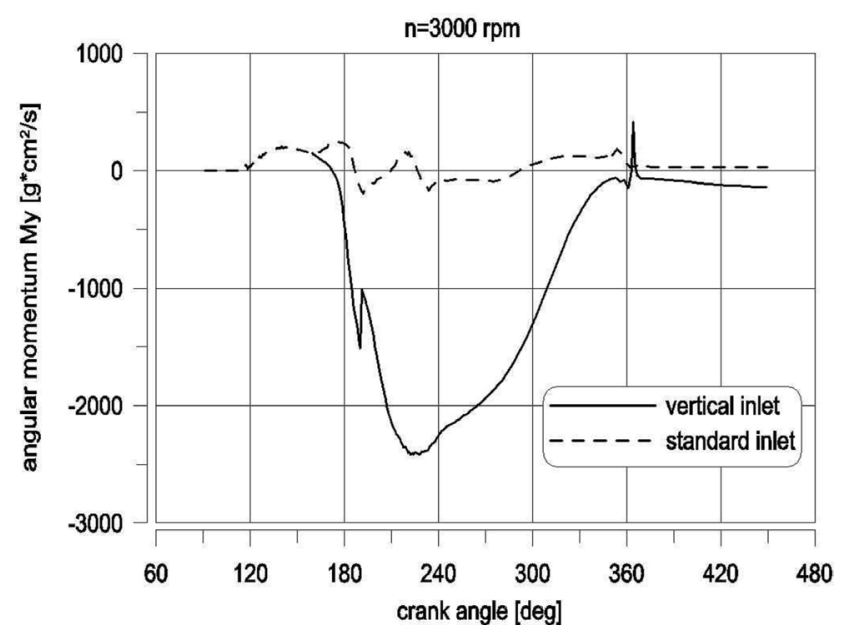

Fig. 8. Comparison of angular momentum of charge in cylinder with vertical and standard inlet at $3000 \mathrm{rpm}$

Rys. 8. Porównanie momentu obrotowego ładunku w cylindrze z pionowym $i$ standardowym dolotem przy $3000 \mathrm{obr} / \mathrm{min}$ $110^{\circ} \mathrm{OWK}$ po GMP i $140^{\circ} \mathrm{OWK}$ przed GMP. Usytuowanie kanałów dolotowych oraz wielkość ciśnienia doładowania wpływa na proces wlotu powietrza do cylindra. Silnik ze standardowym kanałem dolotowym wykazuje większy przepływ powietrza do kanału wylotowego i mniejsze oczyszczenie cylindra ze spalin (mniejszy współczynnik napełnienia). Środek cylindra jest wypełniony gazami spalinowymi. Drugi przypadek wskazuje bardziej równomierny rozkład powietrza wewnątrz cylindra. Umożliwia on bardziej intensywny ruch ładunku (większy ruch beczkowy) niż w standardowej wersji. Rozkład udziału masowego tlenu (proporcjonalnie także powietrza) dla dwóch przypadków przy położeniu tłoka $140{ }^{\circ} \mathrm{OWK}$ przed GMP przedstawiono na rys. 7.

Większy ruch beczkowy ładunku w cylindrze $\mathrm{z}$ pionowym kanałem dolotowym jest potwierdzony przez obliczenie kątowego momentu względem osi x-y-z. Różnica występuje dla momentu My względem osi y (rys. 8), gdzie gwałtowny

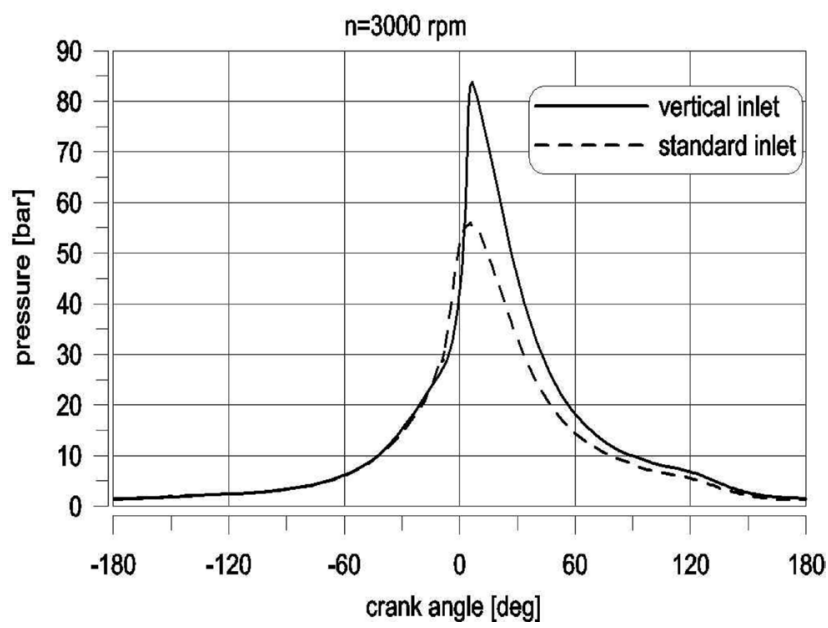

Fig. 9. Comparison of pressure in cylinder with vertical inlet and standard inlet at $3000 \mathrm{rpm}$

Rys. 9. Porównanie ciśnienia $w$ cylindrze z pionowym oraz standardowym kanałem dolotowym przy prędkości obrotowej $3000 \mathrm{obr} / \mathrm{min}$ 


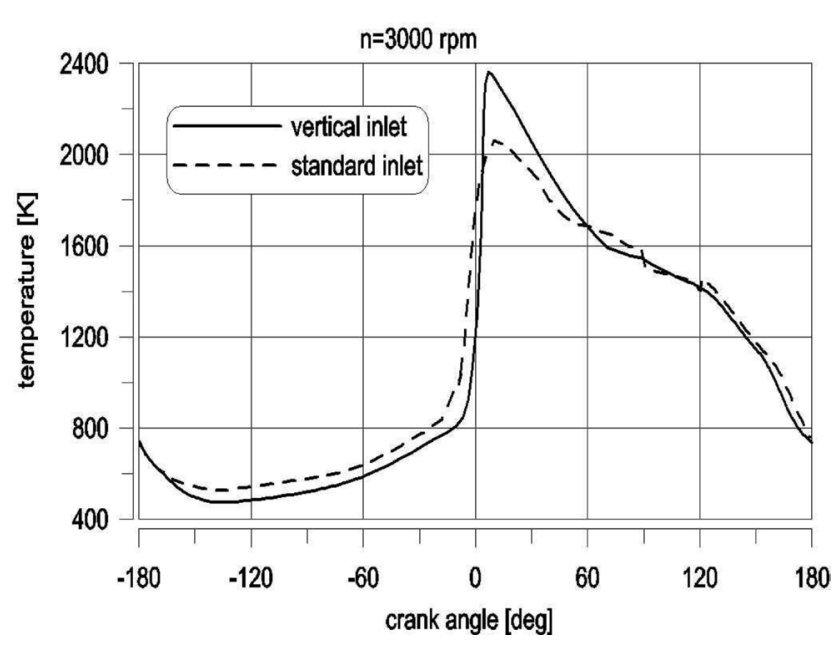

Fig. 10. Comparison of temperature in cylinder with vertical inlet and standard inlet

Rys. 10. Porównanie temperatury w cylindrze silnika z pionowym $i$ standardowym kanatem dolotowym

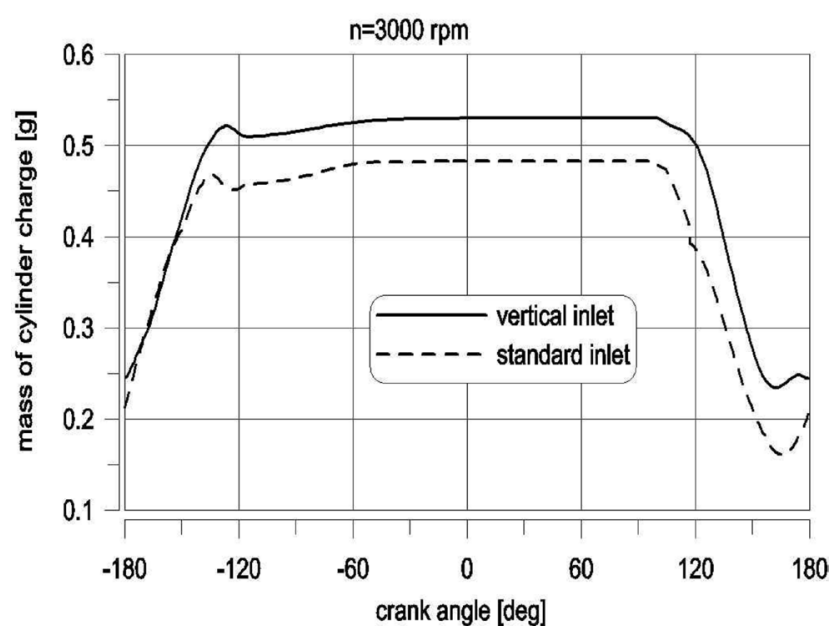

Fig. 11. Comparison of charge mass in cylinder with vertical inlet and standard inlet

Rys. 11. Porównanie masy ładunku w cylindrze z pionowym i standardowym kanatem

More intensive air motion in cylinder and thus higher volumetric efficiency influences also on thermodynamic parameters, particularly on cylinder pressure (Fig. 9). Engine with vertical inlet pipes reaches higher maximum pressure than standard version and therefore indicates also higher IMEP. However higher maximum pressure causes higher charge temperature, which influences on thermal loads of engine (Fig. 10). The engine with standard inlet pipes indicates low maximum temperature despite the same fuel dose per cycle. It can be noticed that lowest mean temperature during scavenge process is higher than $450 \mathrm{~K}$ and for comparison in four-stroke engine is lower than $400 \mathrm{~K}$.

Influence of different types of inlet pipes on the air filling in engine is shown in Fig. 11. Calculations carried out in KIVA showed a significant increase of charge mass in the cylinder for the case with vertical inlet pipes. The charge system enables also a very low "back outflow" during scavenge process. More air in the cylinder gives wzrost tej wielkości pojawia się dla kanału pionowego przy $230{ }^{\circ} \mathrm{OWK}\left(130^{\circ} \mathrm{OWK}\right.$ przed GMP). Takie rozwiązanie jest bardziej przydatne dla proponowanego silnika dwusuwowego.

Bardziej intensywny ruch powietrza w cylindrze i tym samym większy współczynnik napełnienia wpływa także na parametry termodynamiczne, szczególnie na ciśnienie w cylindrze. Silnik z pionowymi kanałami dolotowymi osiąga większe maksymalne ciśnienie niż silnik w standardowej wersji i z tego powodu wykazuje także większe $\mathrm{p}_{\mathrm{i}}$ (rys. 9). Jednakże większe maksymalne ciśnienie powoduje również wyższą temperaturę ładunku, która wpływa na obciążenie termiczne silnika (rys. 10). Silnik ze standardowym kanałem dolotowym wykazuje niższą temperaturę ładunku, pomimo tej samej dawki paliwa na cykl. Można zauważyć, że najniższa średnia temperatura ładunku podczas procesu przepłukania jest większa niż $450 \mathrm{~K}$; dla porównania w silniku czterosuwowym jest mniejsza niż $400 \mathrm{~K}$.

Wpływ różnych typów kanałów dolotowych na napełnienie cylindra powietrzem jest przedstawiony na rys. 11 . Obliczenia przeprowadzone w programie KIVA wykazują znaczący wzrost masy w cylindrze dla przypadku z pionowym kanałem dolotowym. Taki system dolotu umożliwia także bardzo mały „przepływ powrotny” w czasie procesu przepłukania. Więcej powietrza w cylindrze daje możliwość zwiększenia dawki paliwa i w ten sposób uzyskania większej mocy.

\section{Szkodliwe składniki spalin}

W dwusuwowym zaworowym silniku jest bardzo krótki czas potrzebny na proces przepłukania, a także bardzo długi okres „przekrycia” zaworów. Takie zjawisko powoduje niecałkowite oczyszczenie komory spalania z gazów spalinowych. Z powodu bardzo dużej recyrkulacji wewnętrznej gazów spalinowych i mniejszej temperatury gazów stężenie tlenków azotu jest mniejsze niż w klasycznym silniku czterosuwowym. Symulacja pracy silnika ze współczynnikiem nadmiaru powietrza $\lambda=1,05$ wykazała, że udział objętościowy $\mathrm{NO}_{\mathrm{x}}$ w cylindrze jest na stałym poziomie po procesie spalania. Udział molowy tlenków azotu w doładowanym silniku przy ciśnieniu doładowania 1,8 bar (rys. 12) osiąga największą wartość 1000 ppm przy prędkości obrotowej 3000 obr/min.

Powstawanie gazowej mieszanki paliwowo-powietrznej po wtrysku paliwa jest bardzo ważnym czynnikiem z powodu bardzo krótkiego czasu na odparowanie. Na rysunku 13 przedstawiono zmianę ciekłego paliwa w parę po procesie wtrysku. Ciekłe paliwo zaczyna już odparowywać podczas procesu wtrysku. Całkowita masa wtryśniętego paliwa wynosiła $0,02 \mathrm{~g}$ i to paliwo zostało bardzo szybko zużyte podczas procesu spalania.

W wyniku wewnętrznego EGR wtryśnięte paliwo nie jest dokładnie wymieszane z powietrzem i podczas procesu spalania powstaje tlenek węgla. W cylindrze znajduje się objętościowo około 0,2\% CO (rys. 14) tuż przed otwarciem zaworu wylotowego. Gazy wylotowe zawierają około $4 \%$ tlenu w całej objętości. 
possibility to increase of fuel dose and thus to obtain higher engine power.

\section{Exhaust gas pollutants}

Two-stroke valved engine has very short time for scavenge process and opening of inlet and exhaust valves overlap in the long period. This causes non full cleaning of the combustion chamber from exhaust gases. Because of high internal exhaust gas recirculation and lower gas temperature the concentration of nitrogen oxides is lower than in classical four-stroke engine. The simulation of engine work with air excess ratio $\lambda=1.05$ has indicated volumetric fraction of $\mathrm{NO}_{\mathrm{x}}$ in the cylinder on constant level after combustion process. Molar fraction of nitrogen oxides in the charged engine with charging pressure 1.8 bar is shown in Fig. 12 at highest level of $1000 \mathrm{ppm}$ at rotational speed $3000 \mathrm{rpm}$.

Formation of the gaseous fuel mixture after fuel injection is very important factor because of very short time for evaporation. Figure 13 presents a change of liquid fuel into vapour after injection process. Liquid fuel begins evaporate during injection process. Total mass of injected fuel amounted $0.02 \mathrm{~g}$ and fuel was consumed during combustion process very quick.

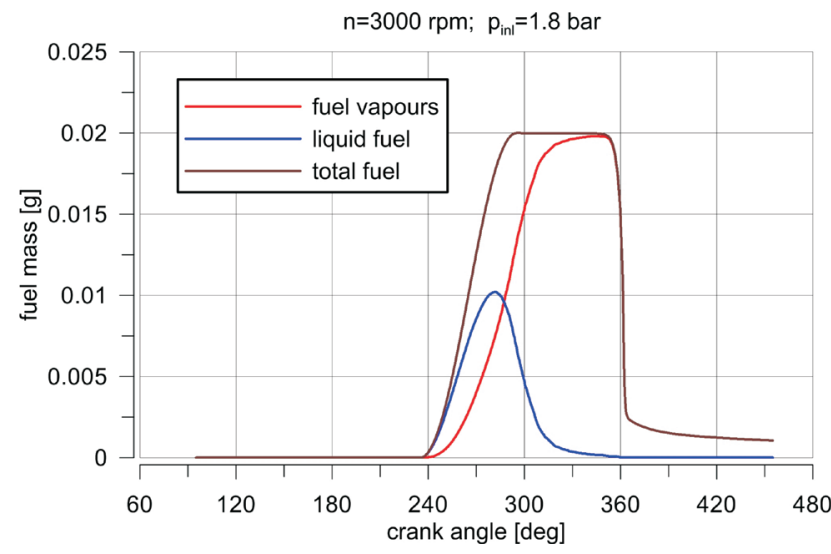

Fig. 13. Fuel mass variation in the cylinder of the charged engine at $3000 \mathrm{rpm}$

Rys. 13. Zmiana masy paliwa w cylindrze silnika doładowanego przy prędkości obrotowej $3000 \mathrm{obr} / \mathrm{min}$

As a result of internal EGR the injected fuel is not thoroughly mixed the air and carbon monoxide is produced during combustion process. In the cylinder is about $0.2 \%$ of molar fraction of $\mathrm{CO}$ (Fig. 14) before the opening of exhaust valves. The exhaust gases contain about $4 \%$ of oxygen in whole volume.

\section{Conclusions}

From the carried out analysis of poppet valve twostroke engine the following conclusions and remarks can be drawn:

1. Application of poppet valve two-stroke engine enables the occurrence of significant downsizing effect with possibility of working both in two- or four stroke operation. Application of electronically controlled hydraulic valve system enables realization of 2/4-stroke work cycle.

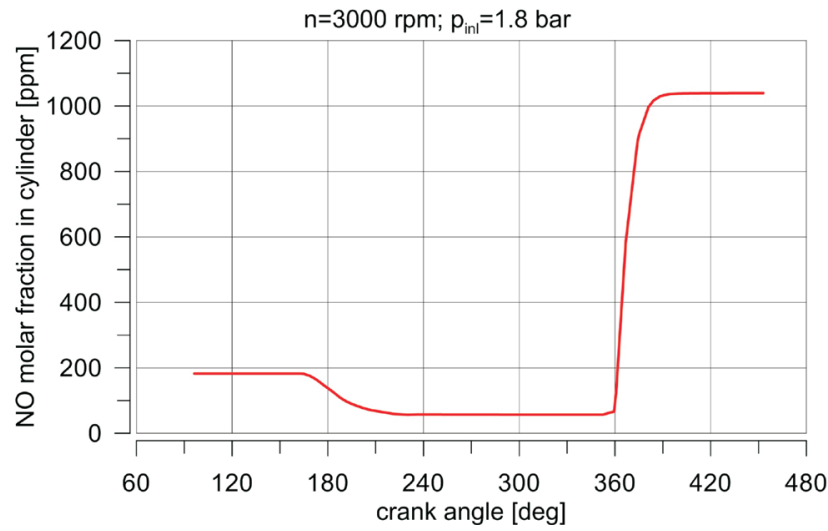

Fig. 12. Cylinder molar fraction of $\mathrm{NO}_{\mathrm{x}}$ in charged engine (inlet pressure 1.8 bar) at $3000 \mathrm{rpm}$

Rys. 12. Udziat molowy NO w cylindrze w silniku doładowanym (ciśnienie wlotowe 1,8 bar) przy 3000 obr/min

\section{Wnioski}

Na podstawie przeprowadzonej analizy pracy zaworowego dwusuwowego silnika spalinowego podano następujące wnioski i spostrzeżenia:

1. Zastosowanie zaworowego dwusuwowego silnika przyczynia się do wystąpienie tzw. efektu ,downsizingu" z możliwością pracy zarówno w trybie dwu-, jak i czterosuwowym. Zastosowanie elektronicznie sterowanego hydraulicznego systemu zaworowego umożliwia realizację 2/4-suwowego cyklu roboczego.

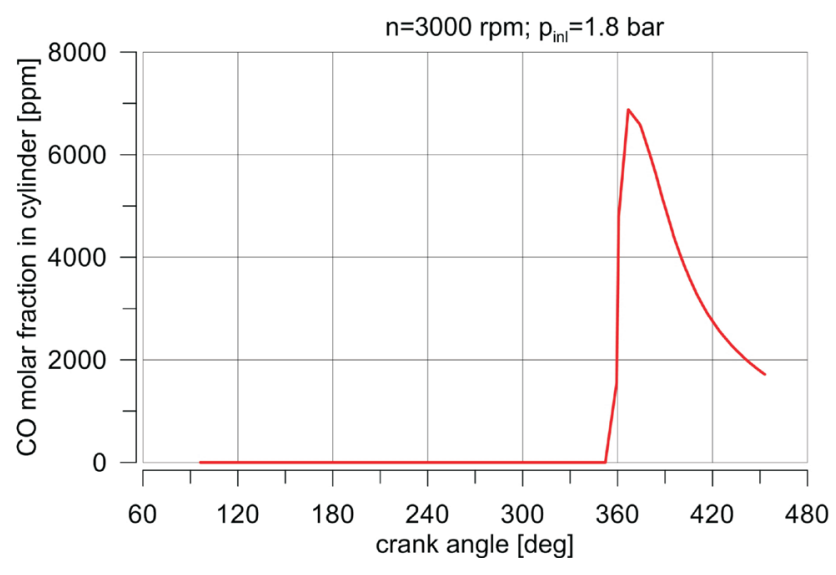

Fig. 14. Molar fraction of $\mathrm{CO}$ in the cylinder of charged engine at $3000 \mathrm{rpm}$

Rys. 14. Udziat molowy CO w cylindrze silnika doładowanego przy prędkości obrotowej $3000 \mathrm{obr} / \mathrm{min}$

2. Dwusuwowy silnik oparty na konstrukcji czterosuwowej zmniejsza straty tarcia prawie o $50 \%$ i zmniejsza jednostkowe zużycie paliwa o około $5 \%$ w porównaniu z silnikiem czterosuwowym.

3. Redukcja emisji dwutlenku węgla jest uzyskiwana przez zmniejszenie jednostkowego zużycia paliwa.

4. Większa sprawność napełnienia w wyniku bardziej intensywnego wlotu powietrza i w ten sposób większe $\mathrm{p}_{\mathrm{e}}$ mogą 
2. Two-stroke engine based on four-stroke design may reduce engine friction losses up to $50 \%$ and decrease of $\mathrm{BSFC}$ about $5 \%$ in comparison to four-stroke engine.

3. Reduction of carbon dioxide emission is obtained by drop of brake specific fuel consumption.

4. Higher volumetric efficiency with more intensive air inflow and thus the higher BMEP can be achieved by proper inlet port design with almost vertical inlet pipe.

5. The increase of engine efficiency, what can be achieved by proper choice of valve timing, should help to fulfil the future high limitations of exhaust emission imposed by low restrictions.

6. The proper work of poppet valves in two stroke engines is possible at applying of a turbocharging system.

7. Internal EGR favours of small quantities of $\mathrm{NO}_{\mathrm{x}}$ and fast fuel evaporation. Also amount of $\mathrm{CO}$ is not so high.

It is possible to adjust engine load by variation of intake pressure (VTG, waste gate, additional charger etc.) without throttle application. być uzyskane dzięki właściwemu ukształtowaniu dolotu $\mathrm{z}$ prawie pionowym ustawieniem kanału wlotowego.

5. Przyrost sprawności silnika, co może być uzyskane przez odpowiedni dobór faz rozrządu, powinien być pomocny do spełnienia przyszłościowych ograniczeń emisji gazów wylotowych.

6. Prawidłowa praca zaworowego silnika dwusuwowego jest możliwa przez zastosowanie systemu turbodoładowania.

7. Wewnętrzna recyrkulacja spalin przyczynia się do powstawania małej ilości $\mathrm{NO}_{\mathrm{x}}$ i szybszego odparowania paliwa. Również ilość CO w spalinach nie jest duża.

Istnieje możliwość regulacji obciążenia silnika dzięki zmianie ciśnienia na dolocie (VGT, zawór upustowy, dodatkowa sprężarka itd.) bez stosowania przepustnicy powietrza.

\section{Nomenclature/Skróty i oznaczenia}

IMEP indicated mean effective pressure/średnie ciśnienie indykowane

FMEP friction mean effective pressure/średnie ciśnienie strat tarcia

$\mathrm{k} \quad$ engine cycle coefficient $(\mathrm{k}=2$ for four-stroke engine and $\mathrm{k}=1$ for two stroke engine)/wspótczynnik rodzaju pracy silnika $(k=2$ dla silnika czterosuwowego $i k=1$ dla dwusuwowego)

n engine speed/prędkość obrotowa

$\mathrm{N}_{\mathrm{e}} \quad$ brake power/moc efektywna

$\mathrm{V}_{\mathrm{ss}} \quad$ total engine capacity/calkowita objętość skokowa A, B empirical coefficients of FMEP linear function/empiryczne wspótczynniki liniowej funkcji aproksymującej średnie ciśnienie strat tarcia

$\eta_{\mathrm{m}} \quad$ mechanical efficiency/sprawność mechaniczna

BMEP brake mean effective pressure/średnie ciśnienie efektywne

EVO exhaust valve opening/otwarcie zaworu wylotowego

EVC exhaust valve close/zamknięcie zaworu wylotowego

IVO intake valve opening/otwarcie zaworu dolotowego

IVC intake valve close/zamknięcie zaworu dolotowego

\section{Bibliography/Literatura}

[1] Basshuysen R., Schaefer F. Internal combustion engine Handbook. SAE International, 2004.

[2] Blair G.P. Design and simulation of two-stroke engines. SAE Inc., 1996.

[3] Das S., Dent J.C. A CFD study of a 4-valved fuel injected twostroke spark ignition engine. SAE Technical Paper 930070, 1993.

[4] GT-Power user's manual. Gamma Technologies, V.6.2, 2006.

[5] Heywood J.B. Internal combustion engines fundamentals. McGraw-Hill Inc., 1988.

[6] Mitianiec W., Buczek K. A new approach in development of two-stroke engines. PTNSS-2009-SC-042, Bielsko-Biala 2009.
[7] Mitianiec W., Buczek K. A new design of ecologic two-stroke engine. Proceedings of 12th EAEC European Automotive Congress, Bratislava 2009.

[8] Mitianiec W., Buczek K. A valved two-stroke engine as a new power source. Journal of Kones Powertrain and Transport, 3 (16), 2009, 259-268.

[9] Nakano M., Sato K., Ukawa H. A two-stroke cycle gasoline engine with poppet-valves in the cylinder head. SAE Technical Paper 901664, 1990.

[10] Osborne R. et al. The 2/4SIGHT project - development of a multi-cylinder two-stroke/four-stroke switching gasoline engine. JSAE Paper 384-20085400, 2008.

[11] Wajand J.A., Wajand J.T. Tłokowe silniki spalinowe średnioi szybkoobrotowe. WNT, Warszawa 2005.
Konrad Buczek, MSc., - Engine Designer of FEV Poland, graduate student of $\mathrm{PhD}$ studies at Cracow University of Technology.

Mgrinż. Konrad Buczek-konstruktor silników spalinowych w FEV Polska, absolwent studiów doktoranckich na Wydziale Mechanicznym Politechniki Krakowskiej. e-mail: buczek@fev.com

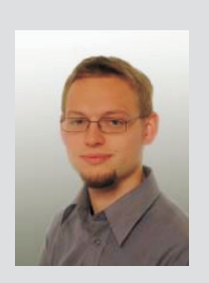

Władysław Mitianiec, DSc., DEng. - Professor of Cracow University of Technology in the Faculty of Mechanical Engineering at CUT.

Dr hab. inz. Władysław Mitianiec-profesor nadzwyczajny na Wydziale Mechanicznym Politechniki Krakowskiej.

e-mail:wmitanie@usk.pk.edu.pl 